\section{臨床}

成人特発性慢性寒冷血色素尿症の 1 例

\title{
AN ADULT CASE OF IDIOPATHIC CHRONIC PAROXYSMAL COLD HEMOGLOBINURIA
}

Masataka OKuno, MD, Kiyoshi Kawal, MD, Eiichi Tomita, MD,

Takashi Kano, MD, Tetsu TAKAI, MD and Yasutoshi Muto, MD

The First Department of Internal Medicine, Gifu University

School of Medicine, Gifu

Reiji KanNAGI, MD

Department of Clinical Laboratory, Faculty of Medicine,

Kyoto University, Kyoto

\begin{abstract}
概要 慢性経過を示した特発性発作性寒冷血色素杘症の 1 成人例を報告し, 文献的考察を加光 た，症例は41才，男性。1978年冬期，先行する熱性疾患を伴わず，寒冷に曝露した後暗褐色尿 に気付き，以後每年同様の症状を繰り返すため，1984年 1 月精查目的にて当科入院. 負血なし， 肝脾腫なし，入院時検査所見で，へモグロビン尿 $(+)$, Ehrlich指試験 $(+)$, Rosenbach試験 $(+)$, Donath-Landsteiner試験 $(+)$ ，抗体価 4 倍であり発作性寒冷血色素㽷症と診断した。血 清梅毒反応 (一), TPHA (一)で, 血清抗体価はマイコプラスマ,ムンプス, 麻疹, 単純へル ペス，EBウイルスいずれも陰性ないし低值を示した。経過中，寒冷を隦けることで血色素尿は 消失した。非梅毒性の症例は検索し得た範囲では本邦28例であり，成人例は6例の及である. さらに先行感染を伴わない例は自験例を含め 2 例に寸ざない：委たSokolら ${ }^{344}$ は1981年をで20 年間に14例を報告，13例が急性型で，古典的な慢性型は成人 1 例のみであつたとしている，本 例は，発症年令，先行感染を伴わない点，年余にわたる溶血発作を繰り返す慢性型である臨床 経過から極めて稀有な症例であると考兄られた。
\end{abstract}

\section{緒 言}

発作性寒冷血色素杘症 (paroxysmal cold hemoglobinunia以下PCHと略す) は自己免疫性 溶血性疾患の一つで, 寒冷曝露後に溶血を起こし， へモグロビン尿をさたす疾患である1，その病因 としては，IgG完全抗体であるDonath-Landsteiner抗体 (D-L抗体)が寒冷曝露に上り補体とと もに患者赤血球と抗原抗体反心を起こし，引き続

[昭和 59 年 8 月 13 日受稿]
き体温により温められて補体系が活性化されるこ とにより，血管内溶血が若起されるとみなされて いる. PCHは梅毒性と非梅毒性に分けられ，古く は梅毒に稅発するものが活とんどを占め，寒冷に より溶血発作を繰り返す慢性型であつたが，そ の後50年を経て梅毒の減少とともに，この様な慢 性型の症例は極めてまれとなり，代つて非梅毒性 の症例が散見される様になつてきた。特に小児が ウイルス性感染後一過性に罹患し，短期間のうち にD-L抗体が消失する急性型 (acute transient 
type）その大半を占める様になつてきている しかし，最近著者らは，なんら先行する感染症を 伴わず，数年来冬期寒冷暴露により溶血発作を繰 り返した特発性慢性発作性寒冷血色素尿症の 1 成 人例を経験した。本例は，発症年令およびその様式 が極めて稀有であると考えられたので，若干の文 献的考察を加之報告する。

$$
\text { 症例 }
$$

患者：41才，男性，セメント工場勤務.

主訴： 寒冷瀑露後の暗褐色尿, 腰痛, 膝関節 痛.

既往歴：25才時，副鼻腔炎手術，29才時，痔 核手術を受けている。

現病歴：1978年11月頃より寒い日に屋外で作 業した後，暗褐色尿が出る様になり，特に㷌宅後 入浴等で体を温めると尿の色調が濃くなつた，先 行する熱性疾患はなく、早朝尿に異常はなかつた。 他に症状はないため放置，その後子冬期に限つて 暗褐色尿が出現した。今回，1983年12月より暗褐 色尿が数回出現, 加卉て腰痛, 滕関節痛も出現し たため，当科外来を受訩，精査のため入院した。
入院時現症：身長 $160 \mathrm{~cm}$ ，体重 $54 \mathrm{~kg}$ ，栄養良 好，脈拍76/分，整，呼吸16/分，整，血圧112/76 $\mathrm{mmHg}$ 。結膜に黄染，貧血なし，心肺所見なし。 腹部平坦軟，肝脾触知せず，浮腫なし，表在リン パ節触知せず，皮唐に所見なし，神経学的異常所 見なし。

入院時唡查成績(表 1，表 2)：入院時検尿で は，外観は淡黄色透明，蛋白 (一), 潜血 (一), 沈泪にも特に所見は認められなかつた。検血では， 赤血球数，血色素，白血球数，血小板数に異常な く,網赤血球数增加なく, 赤血球の fragmentation もみられなかつた．生化学検査ではハプトグロビ ンの低下がみられるが，間接ビリルビン，LDH， カリウム、へモペキシンはいずれも正常範用内で, 血清鉄の減少もなかつた。凝固・線溶系に異常な く, 血清学的検查では, 血清梅毒反応( (一)で, CRP (一), RAテスト(一), LEテスト (一)，免疫グロブリン正常であるが，血清補体価 はCH $\mathrm{CH}_{50}$ が低値を示した.クームステストは再検に ても直接, 間接とも陰性で, 寒冷凝集素価は124倍 と軽度上昇していた。 D-Lテストは陽性で抗体価

表 1. 入院時検查所見

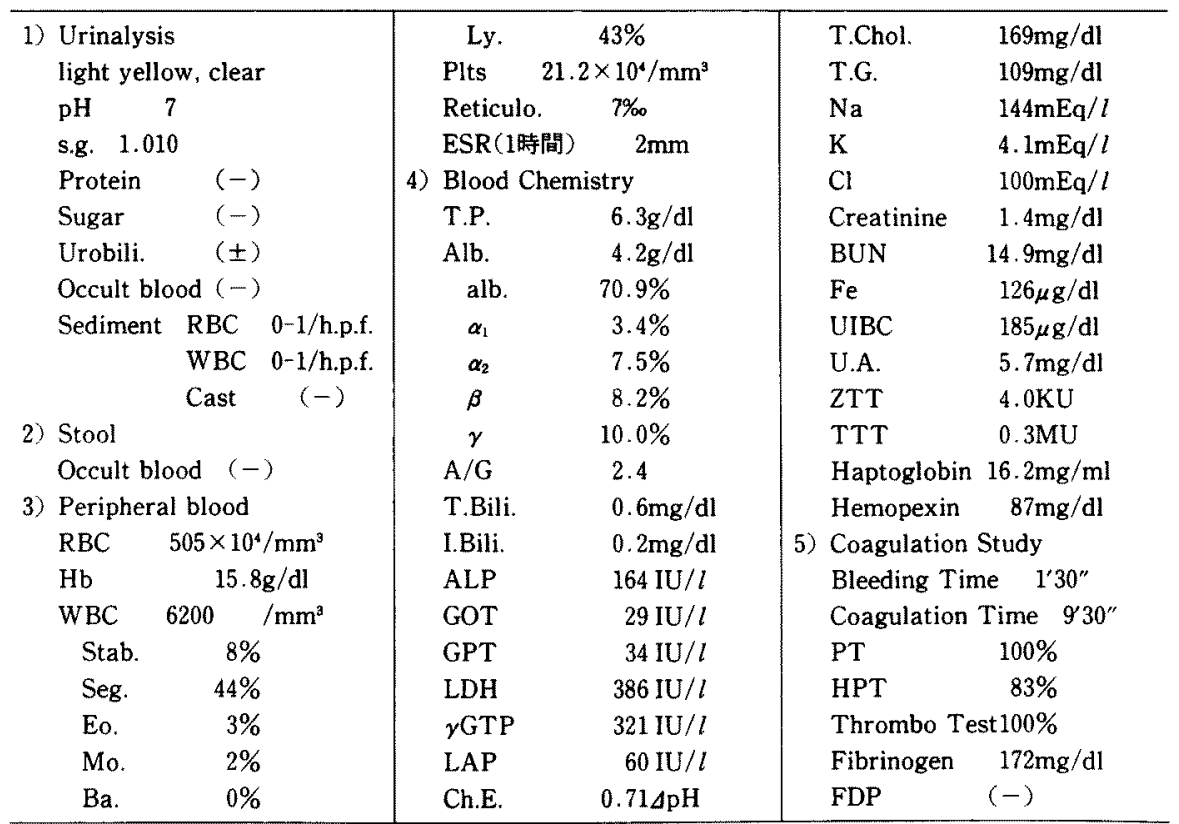


表 2 ，血清学的検查所見

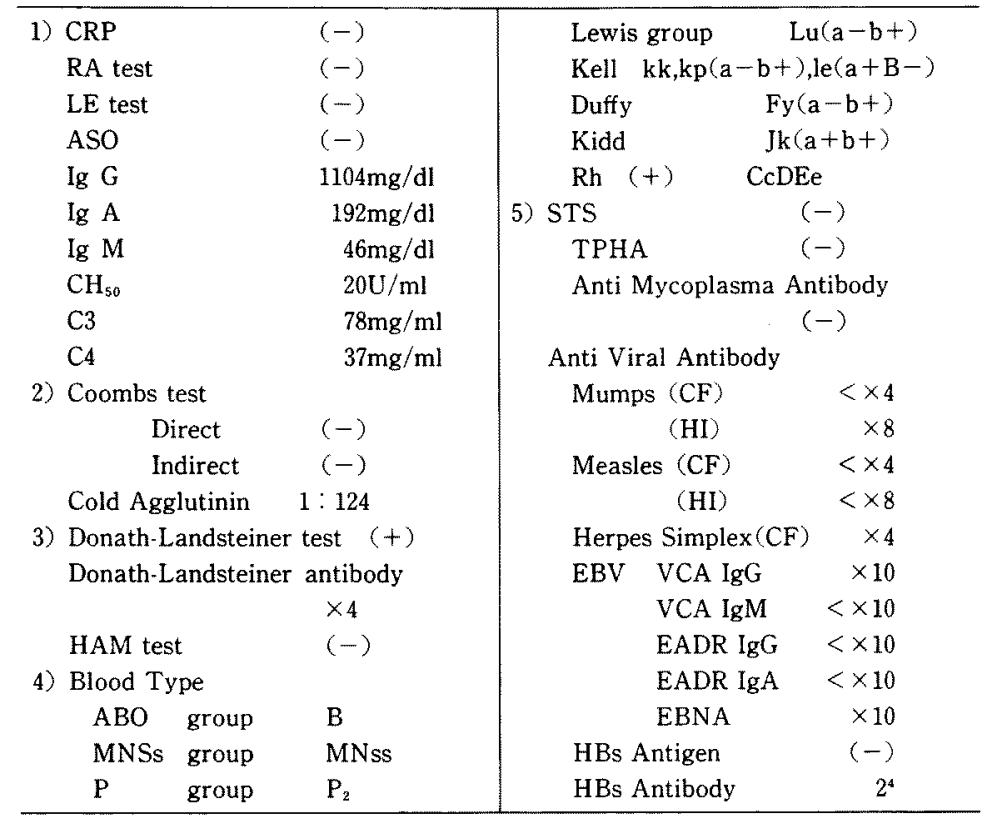

は4 倍であつた。血液型は, B, CcDEe, MNss, $\mathrm{P}_{2}$ であつた。な技，早朝尿に異常なく，Hamテスト （一）であり発作性夜間血色素尿症は否定された。 血清抗体価は，マイコプラスマ，ムソプス，麻疹， 単純ヘルペス, EBウイルスいずれも陰性及至低值 を示した。

入院後検查所見： Ehrlich指試験後指尖より 採血した血液に溶血がみられ，Rosenbach試験で は尿の色調に変化はなかつたが，潜血(十)，蛋白 （十）に対し沈椬で赤血球が認められなかつたこと から血色素尿であると判定した，尿血色素定量で は0.1g/dl以下であつた. 水試験では氷冷した皮膚 にじん麻疹様発疹がみられた，入院中，寒冷曝露 の目的で患者に気温 $5{ }^{\circ} \mathrm{C}$ の屋外を散歩させたとこ 万，暗褐色尿が出現，入浴保温にて更に色調は濃 くなり，血色素 $0.2 \mathrm{~g} / \mathrm{dl}$ 示す血色素尿が誘発され た(表 3 )。同時に行なつた検血では，貧血はみら れなかつたが，間接ビリルビン， LDH $\left(\mathrm{LDH}_{1}\right.$ 優 位）の上昇がみられ，八プトグロビンは入院時よ り更に低下していた。これらは，寒冷により血管 内溶血が起き，血色素の一部は八プトグロビンと
表 3. 寒冷曝露後の検査所見

\begin{tabular}{|c|c|}
\hline \multirow{2}{*}{$\begin{array}{l}\text { 1) Urinalysis } \\
\text { dark brown, clear }\end{array}$} & 2) Peripheral Blood \\
\hline & $496 \times 10^{4} / \mathrm{mm}^{3}$ \\
\hline Protein & $15.2 \mathrm{~g} / \mathrm{dl}$ \\
\hline Bilirubin & $5900 / \mathrm{mm}^{3}$ \\
\hline Occult Blood $(+)$ & Plts $\quad 19.5 \times 10^{4} / \mathrm{mm}^{3}$ \\
\hline Hemoglobin $0.2 \mathrm{~g} / \mathrm{dl}$ & 3) Blood Chemistry \\
\hline Sediment & $1.4 \mathrm{mg} / \mathrm{dl}$ \\
\hline RBC $\quad 0-1 /$ h.p.f. & $0.6 \mathrm{mg} / \mathrm{dl}$ \\
\hline WBC 1 -2/h.p.f. & $621 \mathrm{UU} / l$ \\
\hline Cast & (LDHI $39.5 \%)$ \\
\hline
\end{tabular}

結合，処理されたが，更にその後の保温により溶 血が増悪されたと考觉られた。US，DICにて胆石 症の合併はなく，PSPテストにて腎尿細管機能障 害も認められなかつた．脾シンチで脾の描出正常 で，脾腫はなかつた，入院経過中，寒炩を避ける ことで血色素尿の排泄はみられなくなつた。

寒冷溶血素の性質についてさらに詳しく検討を 加えたところ下記の様な結果が得られた。すなわ ち，患者血清と患者と同型の血球 $\left(B, \mathrm{P}_{2}\right.$ 型 $)$ を用 いたDonath-Landsteiner試験に扎いて，患者血清 
は4倍希釈まで完全溶血を引き起こした。諸種の 稀有な血液型血球を用いたDonath-Landsteiner 試験に扮いては，患者血清はO, $P_{1}$ 型血球 ( 2 名), $\mathrm{O}, \mathrm{P}_{2}$ 型血球 ( 1 名), $\mathrm{O}$, $\mathrm{i}$ 型血球 (1名), ボンベ 亿型血球（1名）をいずれる完全溶血せしめた。 これに対し， $\mathrm{O}, \mathrm{p}$ 型血球 ( 3 名)，B, $\mathrm{p}$ 型血球 ( 1 名), $\mathrm{B}, \mathrm{P}_{2}^{\mathrm{k}}$ 型血球（1名）は全てまつたく溶血さ せなかつた。このことから患者血清中の寒冷溶血 素は抗P特異性を持つことが結論された。ささらに 患者血清をウルトロゲルのカラムクロマトグラ フィーにてIgMとIgGとに分離して，各画分につ いてDonath-Landsteiner試験を行なつたところ， IgM画分には全く溶血活性が観察されず，IgG画 分にのみ強い溶血活性が認められた。このことか ら患者血清中の寒冷溶血素はIgGクラスに属する と考党られた。

\section{考 察}

発作性寒冷血色素尿症 (PCH) はまれな疾患で あり，自己免疫性溶血性疾患の一つにあげられる。 本疾患は古くから気付かれ，とくに，1904年 Donath とLandsteiner ${ }^{5}$ により血清中の二相珄寒 冷血色素（D-L抗体）の存在が明らかにされて以 来, 多くの研究者によりその発生機序が解明され てきた。すなわら，患者は寒冷に曝露すると体表 面温度が低下, 通常 $15^{\circ} \mathrm{C}$ 以下に拈いてD-L抗体が 赤血球と反応する。このD-L抗体のFc部分が補体 $\mathrm{C}_{1} \mathrm{q}$ と反応， $\mathrm{C}_{1} \mathrm{r}$ 作して $\mathrm{C}_{1} \mathrm{~s}$ 活性化し，エステ

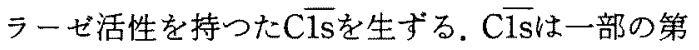

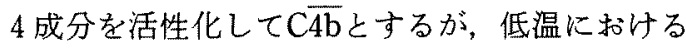
反応はここまでとされている。ついで梁部体温に もどつた赤血球上りD-L抗体の大部分が離れる が, 補体系の反応は進行しC4,C2, C3が次々と活 性化され，classical pathwayを完成させて血管内 溶血が起こるというものである6)，血管内溶血に よる血色素のハプトグロビン飽和能が $135 \mathrm{mg} / \mathrm{dl}$ を越えると腎尿細管機能の限界を越之，血色素尿 が成立する7. 患者は寒冷曝露後入浴にてより強 い血色素尿を呈し，体表面温度の上昇が補体活性 化により拍車をかけたと推測された。

古典的な梅毒性PCHにみられる寒冷溶血素は
IgG画分に存在し，抗P特異性を有し $\mathrm{P}_{1}$ および $\mathrm{P}_{2}$ 赤血球と反応するが， $\mathrm{pp}, \mathrm{P}^{\mathrm{k}}$ 赤血球とは反応しな いとされている8). しかし非梅毒性のPCHに括い ては，特異性の異なる寒冷溶血素の出現頻度が無 視できないとする報告がある。例えばJohnsenら” は, 3 名の小児非梅毒性PCH自験例のうち抗P特 異性をるつるのは1名のみであつたと報告してい る. 本例の寒冷溶血素は古典的な梅毒性 $\mathrm{PCH}$ と同 しく，抗P特異性をもちIgG画分に属する典型的な ものであつた。

PCHは梅毒性と非梅毒性に分けられ，古典的典 型例は梅毒性の慢性型であり，50年前の論文では その病因として梅毒が重要視されていだ)。しか しその後PCHの臨床像は大きな変貌を遂げ，梅毒 性慢性PCHはまれとり，最近では小児がウイル 又性感染後，一過性（多くは1回のみの容血発作 に終る）に䍜患する急性型が大部分を占める様に なつてきている．表 4 に示すように，非梅毒性の 症例は本邦では根本 ${ }^{10)}$ の報告以来文献的に 28 例を かぞえるにすぎないが，そのうち22例が 8 才以下 の小児例であり，成人例はわずかに 6 例のみであ る.しかるもの多くはウイルス感染を思わせる症 状に引き続き発症した急性型で，D-Lテストは 3 ～4 力月以内に陰性化している (self-limited). Sokol ${ }^{3 / 4}$ によると，1981年まで20年間に発見さ れたPCH14例中急性型は13例を占め，古典的な慢 性型はわずかに成人例 1 例のみであつたとしてい る、急性型のらち 1 例を除き全て小児例であり， 汪とんぞが先行するウイルス感染症を有し，通常 1 回の溶血に終り，D-Lテストは全例 2 カ月以内 に陰性化している。この様に, 現在 $\mathrm{PCH}$ の大半を 占める非梅毒性急性型の発症には，先行するウイ ルス感染症が重要であり, 水痘, 麻疮, 流行性耳 下腺炎, 层染性単球症, マイコプラスマに続発し た報告がみられる。これに対し，自験例には現病 歴および血清学的検査（表 2) より先行するウイ ルス感染症を認めず，本た1978年より6 年間にわ たり血色素尿が続いていることから，Dacie ${ }^{111}$ の chronic idiopathic typeにはいる極めて稀有な症

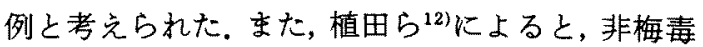


表 4、本邦に括ける非梅害性発作性寒冷血色素氺症

\begin{tabular}{|c|c|c|c|c|c|c|c|c|c|c|c|}
\hline 症例 & 報告者 & 埌告年 & 年 令 & 性 & $\underset{\text { テスト }}{\mathrm{D}-\mathrm{L}}$ & $\begin{array}{c}\text { —モタロ ロ ピン } \\
(\mathrm{g} / \mathrm{dl})\end{array}$ & $\begin{array}{c}\text { 網状赤血球 } \\
(\%)\end{array}$ & $\begin{array}{c}\text { 総ビリルビン } \\
\text { (mg/dl) }\end{array}$ & $\begin{array}{l}\Rightarrow \text { 一ス } \\
\text { テスト }\end{array}$ & 先行感染 & 初発症状 \\
\hline 1 & 根 本 & 1935 & 8 才力月 & 男 & $?$ & $?$ & $?$ & $?$ & $?$ & $(-)$ & 発熱・赤色原 \\
\hline 2 & 恒 松 & 1964 & $57 才$ & 女 & + & $?$ & $?$ & $?$ & $?$ & $(-)$ & $\begin{array}{l}\text { 顔面蓄泉 } \\
\text { 血色 }\end{array}$ \\
\hline 3 & 古 川 & 1964 & $35 才$ & 女 & + & $31 \%$ & 79 & 1.0 & $\begin{array}{l}D(-) \\
I(-)\end{array}$ & $(-)$ & 心窝部痹 \\
\hline 4 & 植 田 & 1971 & $7 才 9$ 力月 & 女 & + & 10.3 & 19 & 2.7 & $\mathrm{D}(+)$ & 上気道感染 & 着色尿 \\
\hline 5 & 侁 藤 & 1972 & $2 才 11$ 力月 & 男 & + & 11.4 & $?$ & $?$ & $\begin{array}{l}\mathrm{D}(+) \\
\mathrm{I}(-)\end{array}$ & 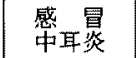 & $?$ \\
\hline 6 & 長谷川 & 1973 & $3 才 1$ 力月 & 男 & $?$ & $?$ & $?$ & $?$ & $?$ & $?$ & $?$ \\
\hline 7 & 近 周 & 1973 & $3 才$ & 女 & + & $?$ & 112 & $?$ & $\mathrm{D}(+)$ & $(-)$ & $\begin{array}{l}\text { 黑血色最 } \\
\text { 熱・腹㜔 }\end{array}$ \\
\hline 8 & 上 島 & 1974 & 7 才。月 & 男 & + & $45 \%$ & 34 & 1.6 & $\begin{array}{l}\mathrm{D}(+) \\
\mathrm{I}(+)\end{array}$ & 水痘 & $\begin{array}{l}\text { 黑褐色屡 } \\
\text { 熱熱 }\end{array}$ \\
\hline 9 & 乾 & 1975 & $1 才 4 力 月$ & 女 & + & 6.1 & 16 & 2.2 & $\begin{array}{l}\mathrm{D}(+) \\
\mathrm{I}(-)\end{array}$ & $\begin{array}{l}\text { 上気道感染 } \\
\text { 腸 } \\
\text { 资 }\end{array}$ & 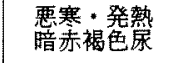 \\
\hline 10 & 乾 & 1975 & $4 才 6$ 力月 & 女 & + & 8.8 & 3.8 & 0.3 & $\begin{array}{l}D(+) \\
I(-)\end{array}$ & $\begin{array}{c}\text { 上気道感染 } \\
\text { 腸 炎 }\end{array}$ & 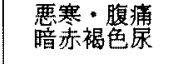 \\
\hline 11 & 籠 崎 & 1975 & $8 才 5$ 力月 & 男 & + & 12.7 & 6 & $?$ & $\begin{array}{l}\mathrm{D}(-) \\
\mathrm{I}(-)\end{array}$ & 上気道感染 & ブドウ酒様原 \\
\hline 12 & 山 本 & 1976 & $1 才 11$ 力 & 男 & + & 6.0 & 14 & 1.55 & $\begin{array}{l}\mathrm{D}(+) \\
\mathrm{I}(+)\end{array}$ & 上気道感染 & $\begin{array}{l}\text { 悪寒·発熱 } \\
\text { 䈐 }\end{array}$ \\
\hline 13 & 建 留 & 1976 & $2 才 11$ 力 & 女 & + & $35 \%$ & 42 & $?$ & $\mathrm{D}(t)$ & $(-)$ & $\begin{array}{l}\text { プド酒色尿 } \\
\text { 顔色不良 }\end{array}$ \\
\hline 14 & 内 田 & 1977 & $2 才$ & 男 & + & $?$ & $?$ & $?$ & $?$ & $(-)$ & $\begin{array}{l}\text { 発熱・血尿 } \\
\text { 顔色不良 }\end{array}$ \\
\hline 15 & 赤 松 & 1978 & $5 才$ & 男 & + & 10.5 & 37 & 1.1 & $\begin{array}{l}\mathrm{D}(-) \\
\mathrm{I}(-)\end{array}$ & $(-)$ & 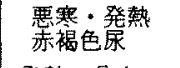 \\
\hline 16 & 吉 田 & 1980 & $3 才 8$ 力月 & 男 & + & 5.4 & 33 & 5.1 & $\begin{array}{l}\mathrm{D}(+) \\
\mathrm{I}(-)\end{array}$ & 感 胃 & 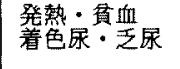 \\
\hline 17 & 平网 & 1979 & $3 才 5$ 力月 & 女 & + & 11.6 & 14 & 3.9 & $\begin{array}{l}\mathrm{D}(+) \\
\mathrm{I}(+)\end{array}$ & $(-)$ & 悪寒·着色尿 \\
\hline 18 & 森 & 1981 & $5 才$ & 女 & + & $?$ & $?$ & $?$ & $\begin{array}{l}\mathrm{D}(+) \\
\mathrm{I}(-)\end{array}$ & RSウイルス & 瞕褐色尿 \\
\hline 19 & 小苗 & 1981 & $1 才 2$ 力月 & 女 & + & $?$ & $?$ & $?$ & $\mathrm{D}(+)$ & $?$ & 血色素尿・黄㾝 \\
\hline 20 & 小倉 & 1981 & 3 才 4 力月 & 男 & + & $?$ & $?$ & $?$ & $\mathrm{D}(+)$ & $?$ & 血色素尿・黄疸 \\
\hline 21 & 布 川 & 1981 & $24 才$ & 男 & + & $?$ & $?$ & $?$ & $D(+)$ & EBウイルス & $\begin{array}{l}\text { 悪寒・発勢 } \\
\text { 棣尿 }\end{array}$ \\
\hline 22 & 小 野 & 1981 & 26 才 & 男 & + & 14.8 & 14 & $?$ & $\begin{array}{l}\mathrm{D}(-) \\
\mathrm{I}(-)\end{array}$ & 上気道感染 & 至身绻急感 \\
\hline 23 & 竹 代 & 1981 & $61 \Varangle$ & 女 & + & 10.2 & 18 & 0.16 & $\mathrm{D}(-)$ & 感 冒 & 黒褐色尿 \\
\hline 24 & 山 本 & 1982 & $1 才 2$ 力月 & 女 & + & 7.8 & 17 & 7.1 & $\begin{array}{l}\mathrm{D}(+) \\
\mathrm{I}(-)\end{array}$ & 腸 炎 & 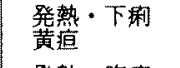 \\
\hline 25 & 山 本 & 1982 & $3 才 4$ 力月 & 男 & + &.$^{7.9}$ & 34 & 0.9 & $\mathrm{D}(+)$ & 感 冒 & $\begin{array}{l}\text { 発勢・腹痛 } \\
\text { 褐色膂 }\end{array}$ \\
\hline 26 & 山本 & 1982 & 3 才出月 & 男 & + & 11.4 & 13 & 0.8 & $\begin{array}{l}\mathrm{D}(-) \\
\mathrm{I}(-)\end{array}$ & 感 冒 & コーラ色尿 \\
\hline 27 & 難，波 & 1983 & $?$ & $?$ & $?$ & $?$ & $?$ & $?$ & $?$ & $?$ & $?$ \\
\hline 28 & 自験例 & 1984 & $41 才$ & 男 & + & 15.8 & 7 & 0.6 & $\begin{array}{l}\mathrm{D}(-) \\
\mathrm{I}(-)\end{array}$ & $(-)$ & 暗褐色䐂 \\
\hline
\end{tabular}

性PCHの臨床経過は短く、しばしばself-limitedで あるとされ（表 5 ）今回我々の文献的調查でも大 半の症例でD-Lテストは $3 \sim 4$ カ月で陰性化して いるのに対し，自験例は非梅毒性ながら数年にわ たり溶血性発作を繰り返しており，本例はまれな
臨床経過を有すると考えられる。本例は長期にわ たりD-Lテスト陽性を持続する可能性があり， $\mathrm{PCH}$ 病因解明上からも今後の経過に興味がも たれる。

なお，PCHでは一般に直接クームステスト陽性 
表 5. 発作性寒冷血色素氺症の各型の特徽

\begin{tabular}{|c|c|c|c|c|}
\hline & $\begin{array}{l}\text { 梅毒 } \\
\text { 発作 } \\
\text { 血色 }\end{array}$ & 寒冷虔 & $\begin{array}{l}\text { 非梅憲性 } \\
\text { 軹作恰 } \\
\text { 血色素家注 }\end{array}$ & $\begin{array}{l}\text { 高寒冾凝集 } \\
\text { 秦価应侯群 } \\
\end{array}$ \\
\hline 発 病 年 令 & 種 & \& & 種 & 通常は成人 \\
\hline 臨 床 释 過 & 長 & $w$ & $\begin{array}{l}\text { 短かく } \\
\text { しばしば } \\
\text { self limited }\end{array}$ & 種名 \\
\hline 全 身 症 状 & 重 & 篤 & 軽 & しばしばない \\
\hline $\begin{array}{l}\text { 寒冾に対する皮 } \\
\text { 忘 }\end{array}$ & 存 & 在 & な & $w$ \\
\hline Raynaud現象 & な & $w$ & な & しばしばある \\
\hline 未佾壊 疽 & な & い & + & $\begin{array}{l}\text { 時として } \\
\text { 怙こる }\end{array}$ \\
\hline 梅毒血清反応 & 陽 & 性 & 陰 & 性 \\
\hline $\begin{array}{l}\text { Donath-Lands- } \\
\text { teiner Test }\end{array}$ & 陽 & 性 & 陽 & 性 \\
\hline 寒命凝集素価 & 正 & 常 & 正 & い. \\
\hline
\end{tabular}

であるとされるが，これは発作直後に限られたこ とであり ${ }^{13)}$ ，自験例でも入院時は陰性であつた。

$\mathrm{PCH}$ と鑑別すべき疾患に，高寒冷凝集素価症候 群, 発作性夜間血色素尿症, 行軍血色素尿症, G6-PD欠損症：ミオグロビン尿症などがある. 自験 例では, 寒冷凝集素価は124倍と軽度高値を示した が，一般に寒冷凝集素症では1000倍以上の高值を 示すといわれる。

$\mathrm{PCH}$ の治療は寒泠を澼けることはもとより，特 に貧血の強い例には輸血が必要となる，輸血に際 しては，P抗原を有する血液が入る可能性があり， $37^{\circ} \mathrm{C}$ に保温して輸血する必要がある。京だ補体成 分を除去した洗浄赤血球が望るしいと思われる。 ステロイド薬, 免疫抑制剂に関しては, 本症がselflimitedであることょりその使用は否定的であ る4，梅毒性PCHには駆梅療法が必要である。

$$
\text { 結語 }
$$

慢性経過を示した特発性発作性寒冷血色素尿症
の 1 成人例を報告し, 若干の文献的考察を加えた。

謝辞 本症例につき，貴重な御助言，御指導をいただき ました島根医科大学内科数授 恒松徳五郎先生に深謝いた します。

\section{文献}

1) Dressler DR: Ein Fall von intermittender Albuminurie unt Chromaturie. Arch Pathol Anat Physiol 6: 264, 1854.

2) Mackenzie GM : Paroxysmal hemoglobinuria : A review. Medicine 8: 159, 1929.

3) Sokol RJ, et al: Autoimmune hemolysis: An 18-year study of 865 cases reflered to a regional transfusion centre. Br Med J 282 : 2023, 1981.

4) Sokol RJ, et al: Autoimmune hemolysis associated with Donath-Landsteiner antibodies. Acta Haemat 68: 268, 1982.

5) Donath $J$ and Landsteiner $\mathrm{K}$ : Uber paroxysmale Haemoglobinurie. Munch Med Wochenschr $51: 1590,1904$.

6）藤本秀巧，他：免疫容血反心，日本臨床 37 : 3947,1979

7）吉田滋彦，他：急性腎不全を合併した非梅毒性発 作性寒椧血色素尿症. 日小会誌 $84 ： 254 ， 1980$.

8) Worllege SM, Rousso C: Studies on the serology of paroxysmal cold hemoglobinuria with special refference to its relationship with the $P$ blood group system. Vox Sang 10:293, 1965.

9) Johnsen HE, et al: Paroxysmal cold haemog. lobinuria in children: 3 cases encountered within a period of 7 months. Scand J Haematol $20: 413,1978$.

10）根本四郎，他：非梅毒性寒冾血色素尿症の 1 例. 日本臨床 $24: 583 ， 1966$.

11) Dacie JV: The hemolytic anemias. Part II The autoimmune hemolytic anemias. Churchill Ltd. London, 1962, p545.

12）植田 楥, 他：小児科診療 $34: 88,1971$.

13）小野 要, 他：診断と治療 $69: 1016,1981$.

14) Bird GMG: Paroxysmal cold hemoglobinuria. Brit J Haematol 37 : 167, 1977. 